\title{
$P-225$ 術前貯血式自己血輸血による同種血輸血回避についての検討
}

\author{
虎の門病院 ${ }^{1)}$ 、同輸血部 ${ }^{2)}$

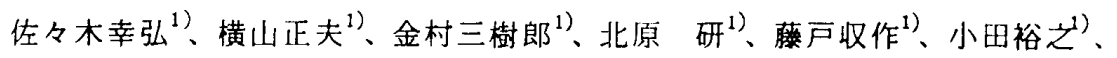

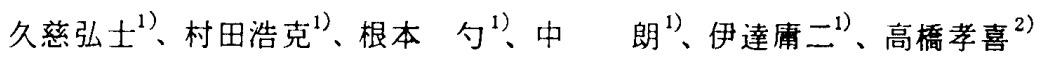

我々は1994年より待期手術に際して術前眝血法による自己血輸血を開始した。今回導入後の同種血輸血の減少 について術式別に検討した。1994年1月より1995年10月まで当科で自己血輸血を併用して手術を施行した54例 を対象にした。年龄は26 83歳 (平均63.6歳)で、男性45例、女性 9 例であった。 $\mathrm{Hb}$ とを確認後 1 回 $400 \mathrm{ml}$ ずつ採血した $400 \mathrm{ml}$ 眝血例ではエリスロ示エチンは使用せず、 $800 \mathrm{ml}$ 以上貯血する際はエ リスロポエチン 6000 単位を週 3 回静注し、週1回、1 3週間で400 1200 m1 眝血し冷蔵保存した。施行した手術は、 前立腺全摘術19例、膀胱全摘術11例、根治的腎摘術 8 例、腎部分切除術 4例、TUR-P 4 例、被膜下前立腺切除 術 3 例、その他 5 例であった。比較対照として自己血輸血導入以前かつ最近の前立腺全摘術 20 例、膀胱全摘術 10 例、根治的腎摘術 20 例を用いた。前立腺全摘術では、導入前 20 例中 17 例 ( $85 \%$ ）で同種血輸血が行われてい た。導入後の19例では、術前 18 例で $800 \mathrm{ml} 、 1$ 例で $400 \mathrm{ml}$ 眝血した。自己血では不足し同種血輸血を要したも のは 6 例 (32\%)で、約 $70 \%$ で同種血輸血を回避できた。膀胱全摘術では、導入前 10 例中 9 例 ( $90 \%$ )で同種 血輸血が行わ扎ていた。導入後の11例では、術前 10 例で $800 \mathrm{ml} 、 1$ 例で $1200 \mathrm{ml}$ 眝血した。同種血輸血を要し たものは $1200 \mathrm{~m} 1$ 眝血した 1 例を含む 8 例（73\%）で、27\%でしか同種血輸血を回避できなかった。根治的腎 摘術では、導入前 20 例中 3 例 $(15 \%)$ で同種血輸血が行われていた。導入後の 8 例では、術前 5 例で $400 \mathrm{ml}$ 、 3 例で $800 \mathrm{~m} 1$ 眝血した。同種血輸血を要したものはなく、10096で同種血輸血を回避できた。

以上より、同種血輸血を回避するためには、前立腺全摘術では $800 \mathrm{ml}$ の眝血でよいが、膀胱全摘術 では不足で眝血量の増量への工夫と手術の㫮熟が必要である。また根治的腎摘術や前立腺肥大症の手術 では拉例を選んで眝血するべきと考えられた。

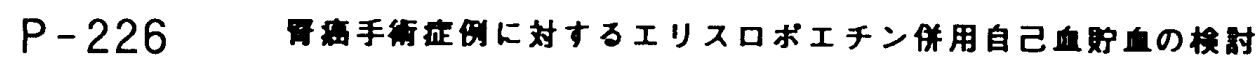

\section{岩手医科大学}

镸谷川道彦、岡本知士、荻生和德、佐藤正跑、松下靖、吉田直人、 石合功一、野村一雄、丹治進、藤岡知昭、久保隆

【目的】自己血輸血は、同㣫血輸血の合併症を回连する手段として広く普及してきた。また、悪性腰就

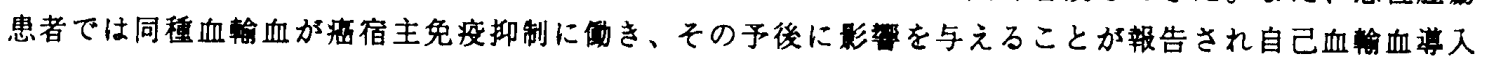

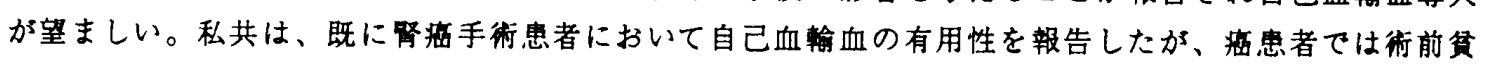
血の状熊、眝血期間の制限や出血空の予想がし鹳いことから導入が制限される。今回、recombinant human erythropoetin（以下EPO）を併用し術前の自己血眝血を行い、非併用自己血眝血群と比较梌討 したので報告する。【対象】根治手術予定の㭾疾患者で年令 70 藏以上、体重 $50 \mathrm{~kg}$ 以上、眝血前 $\mathrm{Hb}$ 值 $11.0 \mathrm{~g} / \mathrm{d} 1$ 以上で重第な合併症を有さない患者を对象とした。自己血躬血は、術前7〜14 日前より3〜4

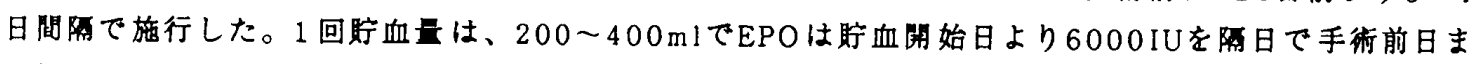
で投与した。貯血した自己血は、CPD液を添加し、4 4 Cの冷蔵庫に保存した。【成絊】对象の内訳は、 $\mathrm{EPO}$ 併用群 5 例、非併用群 15 例で年令、体重に两群間の著明な偏りはなかった。眝血量は、800 117 例、 $1200 \mathrm{~m} 12$ 例、 $1600 \mathrm{~m} 11$ 例。眝血前 $\mathrm{Hb}$ 値は、EPO併用群 $13.9 \pm 1.7 \mathrm{~g} / \mathrm{dl}$ 、非併用群 $15.1 \pm 2.0 \mathrm{~g} / \mathrm{dl}$ で手術直前における Hb值娍少幅は、非併用群 $2.3 \pm 1.0 \mathrm{~g} / \mathrm{d}$ に対してEPO併用群 $1.3 \pm 0.3 \mathrm{~g} / \mathrm{d} l$ と有意に 少なかった。EPO併用群で貯血の中止はなかった。症術中出血贵は、而群間で差はなく、同種血輸血が 必要となったのは非併用群3例でEPO併用群では全例必要なかった。術後7日目のHb值は、EPO併用群 $12.6 \pm 1.0 \mathrm{~g} / \mathrm{d} 1$ に対して非併用群 $11.7 \pm 0.7 \mathrm{~g} / \mathrm{d} 1$ と低值であった。全例に眝血による副作用、監林検查 異常を認めなかった。【結語】EPO件用により貯血性筫血は、軽微であり副作用もなく貯血可能であっ た。また、周術期の体液管理や術後筫血状態の回避からもEPO併用は有用であることが示唆された。 